\title{
Treatment of recalcitrant wastewater and hydrogen production via microbial electrolysis cells
}

\author{
Ruixia Shen ${ }^{1}$, Lixin Zhao ${ }^{1 *}$, Jianwen $\mathrm{Lu}^{2}$, Jamison Watson ${ }^{3}$, Buchun $\mathrm{Si}^{2,3}$, Xi Chen ${ }^{4}$, \\ Haibo Meng ${ }^{1}$, Zonglu Yao ${ }^{5}$, jing Feng ${ }^{1}$, Zhidan Liu ${ }^{2 *}$ \\ (1. Chinese Academy of Agricultural Engineering Planning \& Design, Key Laboratory of Energy Resource Utilization from Agriculture \\ Residue, Ministry of Agriculture and Rural Affairs, Beijing 100125, China; \\ 2. Laboratory of Environment-Enhancing Energy (E2E) and Key Laboratory of Agricultural Engineering in Structure and Environment, \\ Ministry of Agriculture and Rural Affairs, College of Water Resources and Civil Engineering, China Agricultural University, \\ Beijing 100083, China; \\ 3. Department of Agricultural and Biological Engineering, University of Illinois at Urbana-Champaign, Illinois 61801, USA; \\ 4. Department of Civil and Environmental Engineering, Princeton University, Princeton, NJ 08544, USA;
}

5. Institute of Environment and Sustainable Development in Agriculture, Chinese Academy of Agricultural Sciences, Beijing 100081, China)

\begin{abstract}
A large amount of real complex wastewaters are generated every year, which leads to a great environmental burden. Various treatment technologies were deployed to remove the contaminants in the wastewaters. However, these actual wastewaters have not been sufficiently treated due to their complex properties, high-concentration organics, incomplete utilization of hard-biodegradable substrates, the high energy input required, etc. Recently, microbial electrolysis cells (MECs), a great potential technology, has emerged for various wastewater treatment, because not only do they demonstrate satisfactory performance during wastewater treatment, but they also generate renewable $\mathrm{H}_{2}$ as a clean energy carrier. Unlike previous reviews, this review introduced the characteristics of every complicated wastewater, and focused on analyzing and summarizing MEC development for wastewater treatment. The performances of MECs were systematically reviewed in terms of organics removal, $\mathrm{H}_{2}$ production, Columbic efficiency, and energy efficiency. MEC performances for treating actual complex wastewaters and producing $\mathrm{H}_{2}$ can be optimized through operation parameters, electrode materials, catalyst materials, etc. In addition, the challenges and opportunities including complexity of wastewaters, instability of $\mathrm{H}_{2}$ production, robust microorganisms, effect of membrane on two-chamber MEC, and integration of MEC with other treatment processes were deeply discussed. Except for the technical feasibility, both environmental feasibility and economic feasibility also need to meet social requirements. This review can indeed provide a basis for high-efficiency treatment and practical commercial applications of recalcitrant wastewaters via MECs in the future.
\end{abstract}

Keywords: microbial electrolysis cells, complex wastewater, $\mathrm{H}_{2}$ production, renewable energy, energy efficiency

DOI: $10.25165 /$ j.ijabe.20191205.5061

Citation: Shen R X, Zhao L X, Lu J W, Watson J, Si B C, Chen X, et al. Treatment of recalcitrant wastewater and hydrogen production via microbial electrolysis cells. Int J Agric \& Biol Eng, 2019; 12(5): 179-189.

\section{Introduction}

A large amount of wastewater is discharged annually around the world, including municipal wastewater, landfill leachate,

Received date: 2019-04-07 Accepted date: 2019-09-05

Biographies: Ruixia Shen, $\mathrm{PhD}$, research interest: wastewater treatment, Email: shenruixia@cau.edu.cn; Jianwen Lu, PhD, research interest: bio-refinery, Email: jianwenlu2012@126.com; Jamison Watson, PhD candidate, research interest: bio-refinery, Email: jtwatso2@illinios.edu; Buchun Si, PhD, research interest: anaerobic fermentation, Email: sibuchun@cau.edu.cn; Xi Chen, PhD, research interest: wastewater treatment, Email: chenx0710@126.com; Haibo Meng, PhD, Professor, research interests: biomass utilization, Email: menghaibo@, caaepd.org.cn; Zonglu Yao, PhD, Professor, research interests: bio-refinery, Email: yaozonglu@caaepd.org.cn; Jing Feng, PhD, Associate Professor, research interests: anaerobic digestion, Email: fengjing@caaepd.org.cn.

*Corresponding author: Lixin Zhao, PhD, Professor, research interests: anaerobic digestion and bio-refinery, Mailing address: Chinese Academy of Agricultural Engineering, Ministry of Agriculture, Beijing 100125. Tel: +86-10-59196810, Email: zhaolixin5092@163.com; Zhidan Liu, PhD, Professor, research interests: bio-refinery and bio-energy, Mailing address: P.O. Box 67, China Agricultural University, No. 17, Qinghua East Road, Haidian District, Beijing 100083. Tel: +86-10-62737329, Email: zdliu@cau.edu.cn. livestock wastewater, refinery wastewater, industrial wastewater, food-processing wastewater, etc. ${ }^{[1,2]}$. There is many biodegradable organics in these wastewaters, which are potential resources for chemicals and fuels production ${ }^{[3]}$. Conventional methods of wastewater treatment mainly include physical, chemical, and biological technologies (e.g. precipitation, membrane filtration, and fermentation treatment $)^{[4]}$. However, these processes suffer from inevitable limitations, such as low wastewater treatment efficiencies, high-energy consumption, and enormous sludge output $^{[5]}$. In recent years, microbial electrolysis cells (MEC) have been introduced for wastewater treatment. The principle of utilizing MECs for wastewater treatment and $\mathrm{H}_{2}$ recovery is displayed in Figure 1. The organic matters are oxidized in MEC anode via exoelectrogens to release the protons and electrons, and $\mathrm{H}_{2}$ is subsequently generated in MEC cathode with a little applied voltages $\left(\mathrm{E}_{\mathrm{ap}}\right)$, compared with water electrolysis (theoretically calculated to be $0.11 \mathrm{~V}$ vs. $1.21 \mathrm{~V}$ ). Moreover, the $\mathrm{E}_{\text {ap }}$ can be supplied by kinds of sustainable energy sources, such as solar panels, wind energy, and low-grade heat ${ }^{[6]}$. MEC was recognized as a green wastewater treatment technology because it can ${ }^{[7]}$ : (i) utilize a wide source of substrates in the wastewaters; (ii) produce 
three times higher $\mathrm{H}_{2}$ than that produced by traditional dark fermentation, which could meet the market of $\mathrm{H}_{2}$ fuel with an annual growth rate of $6.3 \%$ and reduce the cost of wastewater treatment to some extent; (iii) reduce solid discharge and further reduce handling costs of the sludge; (iv) limit the release of harmful odors and mitigate climate change.

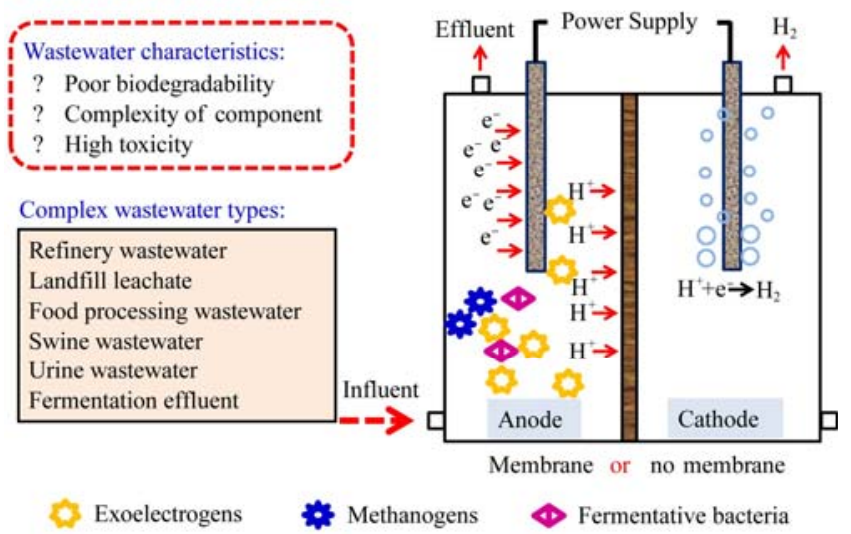

Figure 1 Overview and principle of the MECs for actual wastewater treatment and $\mathrm{H}_{2}$ production

In the past decades, MEC research has made notable progress advancing system configurations and electrode materials, which has improved $\mathrm{H}_{2}$ production efficiency greatly. MEC reactors have been enlarged from lab-scale to pilot-scale with a total volume increasing from $5 \mathrm{~mL}$ to $1000 \mathrm{~L}^{[8]}$. Two typical configurations have been reported, including single-chamber and dual-chamber with H-type ${ }^{[9]}$, cube-type ${ }^{[10]}$, rectangular-type ${ }^{[11]}$, disc-type ${ }^{[12]}$, and cylindrical-type $^{[13,14]}$. In dual-chamber MECs, various kinds of membranes have been utilized as the separator, such as $\mathrm{AEMs}^{[15]}$, $\mathrm{CEMs}^{[16]}, \mathrm{PEMs}^{[17]}, \mathrm{CMMs}^{[18]}, \mathrm{BPMs}^{[18]}$, and $\mathrm{UMs}^{[16]}$. The use of a dual-chamber MEC configuration could obtain purer $\mathrm{H}_{2}$ in the cathode and also prevent $\mathrm{H}_{2}$ from being consumed by methanogens in the anode, which are two major challenges faced by using single-chamber MECs. However, the use of membranes results in a $\mathrm{pH}$ gradient, and increases the total internal resistance. In contrast, single-chamber MECs are advantageous because of their simpler configuration and cheaper cost. However, the $\mathrm{H}_{2}$ production capacity and the purity of $\mathrm{H}_{2}$ are limited in single chamber MECs because of the presence of hydrogenotrophic methanogens, which produce $\mathrm{CH}_{4}$ by combining $\mathrm{H}_{2}$ and $\mathrm{CO}_{2}{ }^{[19]}$. To restrain methanogen metabolism, some effective methods have been adopted, including periodically exposing the cathode chamber to air, lowering the $\mathrm{pH}^{[20]}$, designing shorter retention times, pretreating the inoculum with heat, and adding inhibitors of methanogen growth (e.g. 2-bromoethanesulfonate) ${ }^{[21]}$. In addition, the electrode materials of MEC systems have been widely explored. The anode materials must have a good biocompatibility and the hydrogen evaluation catalytic performance is mostly emphasized by the cathode materials. The cathode materials tested in MECs mainly include carbon-based materials ${ }^{[22]}$, graphite-based materials $^{[23]}$, stainless steel-based materials ${ }^{[24]}$, titanium ${ }^{[25]}$, titanium plate electrode ${ }^{[26]}$, aluminum electrode ${ }^{[27]}$, nickel foam ${ }^{[28]}$, and gas diffusion electrode ${ }^{[29]}$. Some of electrodes have the characteristics of a low cost, good conductivity, lower over-potential, and stable performance ${ }^{[30]}$, making these materials much more suitable for practical MEC application than platinum. So far, partial electrode materials such as stainless steel wire wool in a previous MEC study have been used in pilot-scale experiments ${ }^{[31]}$, but their properties need to be further improved. Finally, for MEC performances, $\mathrm{H}_{2}$ production rates have increased from 0.1 to $50 \mathrm{~m}^{3} / \mathrm{m}^{3} \cdot \mathrm{d}$, mainly through multiple optimizations of reactor configuration, electrode materials, catalyst materials, and experimental parameters ${ }^{[32]}$. In addition, some researches have been reported from other different perspectives, such as biocathode ${ }^{[33]}$, recovery of nutrient ${ }^{[34]}$, energy production $^{[35,36]}$, extracellular electron transfer ${ }^{[37]}$. However, many previous studies just focused on simple substrates such as defined compounds (sodium acetate, glucose, etc.) at the lab scale. Some previous review papers have reported the outstanding results of $\mathrm{MECs}^{[30,38]}$, but few reviews have paid attention to the recalcitrant complex of actual wastewaters.

In this study, we specifically review the development of MECs for complex wastewater treatment and hydrogen production. MEC performances achieved for different types of complex wastewater treatment including TCOD removal rate, $\mathrm{H}_{2}$ production rate, Coulombic efficiency $\left(\mathrm{C}_{\mathrm{E}}\right)$, and energy efficiency were systematically summarized. The challenges and future perspectives from the points of view of integration of MECs with other wastewater treatment processes, the natural complexity of actual wastewaters, the instability of $\mathrm{H}_{2}$ production, and the robustness of mixed culture were discussed in depth with regard to the improvement of wastewater treatment efficiency and $\mathrm{H}_{2}$ production efficiency.

\section{Recent advances on actual complex wastewater treatment via MECs}

In this section, we firstly comprehensively summarized the individual characteristics of various actual complex wastewaters in order of biodegradability difficulty from different fields, such as the petrochemical industry, human activity, food processing, animal activity, and fermentation industry. Different real wastewaters mainly included post-hydrothermal liquefaction wastewater (PHWW), pyrolysis wastewater, de-oiled refinery wastewater, landfill leachate, animal manure wastewater, urine-rich wastewater, brewery wastewater, winery wastewater, dairy wastewater, potato wastewater, molasses wastewater, and fermentation effluent. Subsequently, current performances of MECs for different wastewater treatment were reviewed, which demonstrated significant differences with regard to the wastewater removal efficiency (TCOD or SCOD removal), $\mathrm{H}_{2}$ production rate, $\mathrm{H}_{2}$ content in the gases, $\mathrm{H}_{2}$ yield, energy efficiency, $\mathrm{C}_{\mathrm{E}}$, and current density.

\subsection{Refinery wastewater}

Refinery wastewater mainly includes PHWW, hydrothermal treatment wastewater, pyrolysis wastewater, and de-oiled refinery wastewater. All of the preceding wastewaters originate from different types of refinery processes depending on the primary refinery reaction mechanisms and wastewater produced following physicochemical separation processes like oil-water separation methods ${ }^{[39]}$. Refinery wastewaters mainly consisted of organic acids, furans, and phenolic compounds, which were related to the types of wastewaters they originated from. The individual performances after these wastewaters were treated via MECs are showed in Table 1.

\subsubsection{Post-hydrothermal liquefaction wastewater}

Hydrothermal liquefaction (HTL) is a promising and attractive thermo-chemical conversion technology, which can directly transform wet biomass to valuable biocrude oil at high temperatures $\left(200^{\circ} \mathrm{C}-370^{\circ} \mathrm{C}\right)$ and pressures $(20-23 \mathrm{MPa})^{[44]}$, which can be further refined into transportation fuels. However, PHWW is created as one of the main by-products during this process ${ }^{[45]}$. 
Table 1 Design properties and performances of the MECs fed with refinery wastewaters.

\begin{tabular}{|c|c|c|c|c|c|c|c|c|c|c|c|c|c|}
\hline $\begin{array}{c}\text { Actual } \\
\text { wastewater types }\end{array}$ & $\begin{array}{c}\text { MEC } \\
\text { system }\end{array}$ & $\begin{array}{l}\text { Operation } \\
\text { mode }\end{array}$ & $\begin{array}{l}\text { Anode } \\
\text { material }\end{array}$ & $\begin{array}{l}\text { Cathode } \\
\text { material }\end{array}$ & $\begin{array}{c}\text { MEC } \\
\text { Volume } \\
/ \mathrm{mL}\end{array}$ & Separator & $\begin{array}{l}\text { Catalyst in } \\
\text { cathode }\end{array}$ & $\begin{array}{l}\mathrm{BOD}_{5} / \\
\mathrm{COD}\end{array}$ & $\begin{array}{l}\text { TCOD } \\
\text { removal }\end{array}$ & $\begin{array}{c}\mathrm{H}_{2} \text { production } \\
\text { Rate } \\
/ \mathrm{L} \mathrm{H}_{2} \cdot \mathrm{L}^{-1} \cdot \mathrm{d}^{-1}\end{array}$ & $\begin{array}{l}C_{E} \\
/ \%\end{array}$ & $\begin{array}{l}\eta_{E+S} \\
/ \%\end{array}$ & Ref. \\
\hline PHWW & Dual & Continuous & $\begin{array}{c}\text { Carbon } \\
\text { nanotubes }\end{array}$ & $\begin{array}{c}\text { Carbon fiber } \\
\text { felt }\end{array}$ & 290 & PEM & - & 0.16 & $80.2 \%$ & 0.0039 & 7.0 & $\begin{array}{c}106.5 \\
\left(\eta_{E}\right)\end{array}$ & {$[40]$} \\
\hline APBP & Dual & Continuous & Carbon felt & Carbon cloth & 29.3 & MEA & $\mathrm{Pt}$ & - & - & 4.3 & 54 & 48 & [41] \\
\hline APBP & Dual & Batch & Carbon felt & Carbon cloth & 29.3 & MEA & $\mathrm{Pt}$ & - & $48 \%$ & 2.5 & 79 & 60 & {$[41]$} \\
\hline APBP (sawdust) & Dual & Batch & Carbon felt & Carbon & 16 & Nafion 115 & $\mathrm{Pt}$ & - & $60 \%$ & 5.8 & 98 & - & [42] \\
\hline $\begin{array}{l}\text { Switchgrass } \\
\text { biorefinery stream }\end{array}$ & Dual & Continuous & Carbon felt & Carbon rod & 32 & Nafion 115 & $\mathrm{Pt}$ & - & $74.2 \%$ & 2.92 & 62 & - & [43] \\
\hline $\begin{array}{l}\text { Refinery } \\
\text { wastewater }\end{array}$ & Single & Batch & $\begin{array}{l}\text { Graphite } \\
\text { plates }\end{array}$ & SS mesh & 5 & NO & $\mathrm{NO}$ & - & $79 \%$ & - & - & - & [23] \\
\hline
\end{tabular}

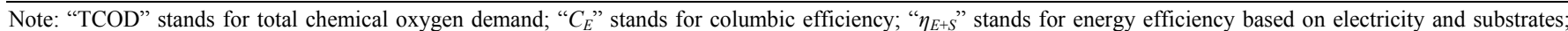
"MEA" stands for membrane electrode assembly; "PEM" stands for proton exchange membrane; "PHWW" stands for post-hydrothermal liquefaction wastewater; " $\eta_{E}$ " stands for energy efficiency based on electricity; "SS" stands for stainless steel; "APBP" stands for aqueous phase from biomass pyrolysis.

PHWW, considered to be an emerging pollutant, has a high concentration of organics and contains hundreds of different types of chemical compounds. The characteristics of these components are entirely dependent on the characteristics of the HTL feedstock and its operational conditions. In general, a considerable organics $(20 \%-50 \%)$ can be transformed into the PHWW ${ }^{[46]}$. In addition, about $60 \%-70 \%$ of the nitrogen from the feedstock is distributed into the $\mathrm{PHWW}^{[47]}$. Many toxic organic compounds are commonly detected in the PHWW produced from biomass feedstock. Specifically, phenols, toluene, benzene, aziridine, 2-methylarizidine, cyclopentenones, and organic acids are all present in the PHWW to some extent ${ }^{[48]}$. Thus, inappropriate disposal of the PHWW could impact the environment and threaten public health ${ }^{[45]}$. Now, studies on HTL have often focused on the biocrude oil production yield, its characteristics, and process nutrients recovery like nitrogen migration and transformation ${ }^{[49]}$, etc. $^{[50]}$, while scant attention is attracted on PHWW utilization and treatment. In recent years, some researchers have treated PHWW using single anaerobic digestion technology ${ }^{[51-53]}$, pretreatment by organic solvents before anaerobic digestion, and microalgae cultivation $^{[4]}$. Although it could produce biogas like methane, partial organic matters in the PHWW were not degraded or had a deleterious effect on fermentative microbes and microalgae, which limited its further development.

Some researchers have demonstrated that the MEC technology itself can remove furaldehyde and 5-HMF without adopting extraction treatment ${ }^{[54,55]}$. Our previous MEC study has achieved the high-efficiency degradation and $\mathrm{H}_{2}$ production of $\mathrm{PHWW}^{[40]}$. However, $\mathrm{H}_{2}$ production rate and efficiency need to be improved in the future by optimizing MEC configurations and operational conditions, and adding cathode catalysts that are cost effective and lead to a high performance. In addition, compared with the above HTL technology, hydrothermal treatment is an important pretreatment method at lower reaction temperatures of $170^{\circ} \mathrm{C}$ $195^{\circ} \mathrm{C}$, which could make biomass highly hydrolysable with cellulytic enzymes for bioethanol production ${ }^{[56]}$. For example, the cotton stalks can be used for producing bioethanol ${ }^{[57]}$, but before putting it to practical use, a hydrothermal pretreatment process was needed to release the cellulose in the wheat straw. After hydrothermal pretreatment, most of the cellulose (96\%) was transferred to the solid fiber fraction. However, during hydrothermal pretreatment, half of the hemicellulose stayed in the hydrolysate (wastewater), and it needed to be treated further ${ }^{[58]}$. When the hydrothermal treatment wastewater produced from wheat straw was treated via dual-chamber MECs, a TCOD removal efficiency of $61 \%$ and an average $\mathrm{H}_{2}$ production rate of $0.61 \mathrm{~L} / \mathrm{L} \cdot \mathrm{d}$ were obtained at $0.7 \mathrm{~V}$ in spite of a lower $\mathrm{C}_{\mathrm{E}}{ }^{[59]}$.

\subsubsection{Pyrolysis wastewater}

Pyrolysis is one of the primary thermochemical technologies to produce renewable fuel from biomass. Generally, biomass for producing bio-oil is rich in water $(\sim 20 \%)^{[41]}$, and this water would be converted into a pyrolysis by-product. The separation of the main products and by-products results in wastewater generation, which mainly consisted of acetic acid, 5-hydroxymethyl furfural (5-HMF), vanillic acid, 3-ethylphenol, 2-methoxyphenol, furfural ${ }^{[41]}$, etc.

Fortunately, the wastewater could be successfully treated via MECs. For example, when MECs was fed with aqueous phase of switchgrass pyrolysis, both COD removal efficiency feasible and the $\mathrm{H}_{2}$ production capacity were considerable. The batch operation achieved a higher $\mathrm{C}_{\mathrm{E}}(79 \%$ vs. $54 \%)$ but lower $\mathrm{H}_{2}$ production rate $(2.5 \mathrm{~L} / \mathrm{L} \cdot \mathrm{d}$ vs. $4.3 \mathrm{~L} / \mathrm{L} \cdot \mathrm{d})$ than those produced in continuous mode ${ }^{[41]}$. Almost all furan aldehydes (furfural), organic acids (acetic acid, propionic acid), sugar derivatives (levoglucosan), and phenolic molecules in the wastewater were degraded through the MECs. Additionally, when the anode liquid was recycled in a continuous MEC, TCOD removal efficiency and $\mathrm{H}_{2}$ production rate were enhanced to a certain extent compared with one-pass operation ${ }^{[43]}$. The reason for this may be due to the acceleration of mass transfer, more complete degradation of pyrolysis wastewater, and the mitigation of kinetic limitations in the anode of the MEC under the circulation mode of the anolyte.

\subsubsection{De-oiled refinery wastewater}

The organic strength and biodegradability of refinery wastewater varies based on the primary oil separation processes. However, the COD values of most refinery wastewaters range from 400 to $1000 \mathrm{mg} / \mathrm{L}$. In addition, this kind of wastewater with a suitable $\mathrm{pH}(7.2-8.9)$ and high conductivity $(1.3-6.4 \mathrm{mS} / \mathrm{cm})$ is beneficial for bioelectrochemical treatment, and higher current densities and lower MEC internal resistances would be obtained ${ }^{[23]}$.

In particular, a previous study has explored the performance of MECs fed with different de-oiled refinery wastewaters from three different refinery facilities, which were from the final combination of all processing wastewaters. It was found that the single-chamber MECs in batch mode showed good performances with regard to TCOD removal $(79 \%)$ and current density $\left(2.1 \mathrm{~A} / \mathrm{m}^{2}\right)$ at an $\mathrm{E}_{\text {ap }}$ of $0.7 \mathrm{~V}^{[23]}$. Then, five model compounds to represent this type of wastewater were chosen to deeply explore its treatment efficiency and degradation mechanism or pathways via the MECs, which included furans and phenolic compounds ${ }^{[54]}$. When a 
mixture of these model compounds were used as the energy or substrate for the MEC bioanode for $\mathrm{H}_{2}$ production in batch mode, the exoelectrogenesis pathway was inhibited and $91 \%$ of the current was reduced with an increase of mixture initial concentration from 0.8 to $8.0 \mathrm{~g} / \mathrm{L}^{[60]}$. This inhibition was mainly due to furanic and phenolic compounds rather than their biotransformation products (catechol and phenol). Compared with batch mode, continuous operation mode may be a good way to decrease the effect of the inhibitors on exoelectrogens of the MEC bioanode. Moreover, a previous study has confirmed that the $\mathrm{H}_{2}$ production rate $(0.22 \mathrm{~L} / \mathrm{L} \cdot \mathrm{d})$ could be enhanced in MECs fed with the mixture in continuous mode at an $\mathrm{E}_{\mathrm{ap}}$ of $1.0 \mathrm{~V}^{[61]}$. In addition, a recent study thoroughly illustrated the biotransformation fate of phenolic compounds and individual contribution extent to exoelectrogens in the MEC bioanode. Based on the individual fermentation extent of these compounds, syringic acid showed the higher fermentative transformation and electrochemical activity compared to other phenolic compounds ${ }^{[62]}$.

\subsection{Landfill leachate}

Landfill leachate has a high pollution potential in soil, groundwater, and poses a large threat to human health ${ }^{[5]}$. Further, landfill leachate's composition is undefined and affected by many factors like the waste type, seasonal variations, landfill age, and soil conditions. The ratio of $\mathrm{BOD}_{5}$ to $\mathrm{COD}$ for young landfill leachate was previously reported as being $>0.30$, intermediate landfill leachate was $0.10-0.30$, and mature landfill leachate was $<0.10^{[15]}$. In addition to biodegradable organics, landfill leachate also has inorganics, VFAs and metal ions ${ }^{[63]}$. Most of the previous studies about bio-electrochemical treatment of landfill leachate focused on the microbial fuel cells (MFCs) ${ }^{[64]}$. Only three studies treated the landfill leachate via MECs (Table 2), and a proper pretreatment of landfill leachate before MEC was necessary and helpful.

Landfill leachate after fermentation pre-treatment had better MEC performances than raw landfill leachate (Current density: $23 \mathrm{~A} / \mathrm{m}^{3}$ vs. $2.5 \mathrm{~A} / \mathrm{m}^{3}$; $\mathrm{C}_{\mathrm{E}}: 68 \%$ vs. $56 \%$; biochemical oxygen demand based on 5 days $\left(\mathrm{BOD}_{5}\right)$ removal efficiency: $83 \%$ vs. $5.6 \%)^{[65]}$. Overall, the pre-fermentation of landfill leachate had two advantages for further MEC treatment: 1) The MEC could obtain simpler organic matter from the fermentation effluent of landfill leachate like succinate, acetate, etc. which were oxidized more directly and easily by the anode-respiring bacteria of MECs; 2) Pre-fermentation of landfill leachate may also remove compounds that are partially toxic to the anode respiring bacteria, like phenolic compounds.

Table 2 Design properties and performances of the MECs fed with landfill leachate, animal manure wastewater, and urine wastewater

\begin{tabular}{|c|c|c|c|c|c|c|c|c|c|c|c|c|c|}
\hline $\begin{array}{c}\text { Actual } \\
\text { wastewater } \\
\text { types }\end{array}$ & $\begin{array}{l}\text { MEC } \\
\text { system }\end{array}$ & $\begin{array}{l}\text { Operation } \\
\text { mode }\end{array}$ & $\begin{array}{l}\text { Anode } \\
\text { material }\end{array}$ & $\begin{array}{l}\text { Cathode } \\
\text { material }\end{array}$ & $\begin{array}{l}\text { MEC } \\
\text { Volume } \\
\text { /mL }\end{array}$ & Separator & $\begin{array}{l}\text { Catalyst } \\
\text { in } \\
\text { cathode }\end{array}$ & $\begin{array}{l}\mathrm{BOD}_{5} / \\
\mathrm{COD}\end{array}$ & $\begin{array}{l}\text { TCOD } \\
\text { removal }\end{array}$ & $\begin{array}{c}\mathrm{H}_{2} \text { production } \\
\text { rate } \\
/ \mathrm{L} \mathrm{H}_{2} \cdot \mathrm{L}^{-1} \cdot \mathrm{d}^{-1}\end{array}$ & $\begin{array}{l}C_{E} \\
/ \%\end{array}$ & $\begin{array}{l}\eta_{E+S} \\
/ \%\end{array}$ & Ref. \\
\hline $\begin{array}{l}\text { Fenton-treated } \\
\text { landfill leachate }\end{array}$ & Dual & Continuous & Graphite rod & Graphite rod & 640 & AEM & NO & 0.31 & $\begin{array}{c}52 \% \\
\left(\mathrm{BOD}_{5}\right)\end{array}$ & - & 29 & - & {$[15]$} \\
\hline $\begin{array}{l}\text { Raw landfill } \\
\text { leachate }\end{array}$ & Dual & Continuous & Graphite rod & Graphite rod & 640 & AEM & NO & 0.31 & $\begin{array}{c}3 \% \\
\left(\mathrm{BOD}_{5}\right)\end{array}$ & - & 1.8 & - & {$[15]$} \\
\hline $\begin{array}{l}\text { Simulated landfill } \\
\text { leachate }\end{array}$ & Dual & Batch & Carbon felt & $\begin{array}{l}\text { Stainless } \\
\text { steel plate }\end{array}$ & 1000 & CEM & NO & - & $62-65 \%$ & 0.04 & $12-41$ & - & [67] \\
\hline $\begin{array}{l}\text { Landfill leachate } \\
\text { via pre-treatment }\end{array}$ & Dual & Batch & $\begin{array}{l}\text { Graphite fibers; SS } \\
\text { rod }\end{array}$ & Graphite rods & 320 & AEM & - & 0.32 & $\begin{array}{c}83 \% \\
\left(\mathrm{BOD}_{5}\right)\end{array}$ & - & 68 & - & [65] \\
\hline $\begin{array}{l}\text { Piggery } \\
\text { wastewater }\end{array}$ & Dual & Batch & $\begin{array}{l}\text { Graphite felt; } \\
\text { Carbon rod }\end{array}$ & $\begin{array}{l}\text { Titanium plate } \\
\text { electrode }\end{array}$ & 720 & $\begin{array}{l}\text { Nafion } 424 \\
\text { Membrane }\end{array}$ & $\mathrm{Pt}$ & - & $48 \%$ & 0.061 & - & 124 & {$[26]$} \\
\hline Swine wastewater & Single & Batch & Graphite fiber brush & Carbon cloth & 28 & NO & $\mathrm{Pt}$ & - & $72 \%$ & 1 & 43 & $190\left(\eta_{E}\right)$ & {$[68]$} \\
\hline $\begin{array}{l}\text { Dairy manure } \\
\text { wastewater }\end{array}$ & Single & Batch & $\begin{array}{l}\text { Graphite } \\
\text { fiber brush }\end{array}$ & Carbon cloth & 28 & NO & $\mathrm{Pt}$ & - & - & - & - & - & [69] \\
\hline Urine & Dual & Batch & Graphite felt & Titanium & 1300 & CEM & $\mathrm{Pt}$ & - & $46 \%$ & 48.6 & 97 & - & [25] \\
\hline
\end{tabular}

Note: "TCOD" stands for total chemical oxygen demand; "BOD 5 " stands for biochemical oxygen demand based on 5 days; " $C_{\mathrm{E}}$ " stands for columbic efficiency; " $\eta_{E++} S$ " stands for energy efficiency based on electricity and substrates; " $\eta_{E}$ " stands for energy efficiency based on electricity; "CEM" is cation exchange membrane; "AEM" is anion exchange membrane; "SS" stands for stainless steel.

Besides fermentation pretreatment, Fenton pretreatment is also an advanced oxidation processes commonly employed for pretreating landfill leachate. Fenton pretreatment of landfill leachate led to a much better MEC performance than that of the raw landfill leachate, leading to an improvement of the $\mathrm{BOD}_{5}$ removal efficiency from $3 \%$ to $52 \%$, and $\mathrm{C}_{\mathrm{E}}$ from $1.8 \%$ to $29 \%{ }^{[15]}$. However, the current density of the MECs fed with the landfill leachate after different pretreatments were still far below the target current density $\left(\sim 140 \mathrm{~A} / \mathrm{m}^{3}\right)^{[15,66]}$.

\subsection{Animal manure wastewater and urine-rich wastewater}

Due to the increasing demand for meat-rich food, large numbers of pigs are being bred in swine farms, and at the same time a considerable amount of swine wastewater is produced every year $^{[68]}$. If swine wastewater was directly discharged into the environment, surface water and well would be polluted ${ }^{[70]}$. Besides, the noxious odors due to the ammonia may be released into the air. Therefore, some feasible treatment methods need to be explored in order to avoid environmental pollution from swine wastewater. In such wastewater, the ratio of $\mathrm{BOD}_{5}$ to $\mathrm{COD}$ has been reported to be $\sim 0.60^{[71]}$. This kind of wastewater has a total solid content of $1 \%-3 \%$ and a TCOD of $12000-17000 \mathrm{mg} / \mathrm{L}^{[71]}$, which consisted of organic matters with high concentrations, phosphorus, salts (e.g. nitrates), microbes, and pharmaceutically active compounds ${ }^{[72]}$.

Kiely et al. firstly tried to treat dairy manure wastewater via MECs, but this experiment failed to produce gases and a current, which probably due to the low content of Geobacter species on MECs anode biofilm ${ }^{[69]}$. However, different from dairy manure wastewater, swine wastewater could be treated effectively (highest TCOD removal: $75 \%$ ) and produced the highest $\mathrm{H}_{2}$ production rate $(1.0 \mathrm{~L} / \mathrm{L} \cdot \mathrm{d})$ via MECs (Table 2). Further, the highest $\mathrm{H}_{2}$ production efficiency (based on the electrical energy) was $91 \%$ in a batch MEC fed with full-strength swine wastewater ${ }^{[68]}$.

Similar to swine wastewater, urine wastewater is also rich in 
nitrogen in the form of urea ${ }^{[25,73]}$. In batch mode, the urine after five times dilution could be used to produce $\mathrm{H}_{2}$ via a dual-chamber MECs, and high $\mathrm{H}_{2}$ production $(48.6 \mathrm{~L} / \mathrm{L} \cdot \mathrm{d})$ and TCOD removal $\left(171.0 \mathrm{~g} \mathrm{COD} / \mathrm{m}^{2} / \mathrm{d}\right)$ were obtained successfully ${ }^{[25]}$. In addition, the urine can be used as the source of ammonia recovery.

\subsection{Food processing wastewater}

In modern society, food production is very important and leads to a variety of different products, including milk, sugars, starches, etc. However, different kinds of wastewaters appeared during different food production processes. In the US, approximately 1.4 billion liters of food processing wastewater can be produced annually ${ }^{[74]}$. Fortunately, most of them are non-toxic because its constituents are mainly simple sugars, starch, cellulose, hemicelluloses, lipids, proteins, organic acids, etc. The specific constituents of the wastewater depend on the raw materials, terminal products, and processing technologies. This type of wastewater has the characteristic of having a high BOD, so it can be readily biodegradable. Based on the above description, these organics-rich food processing wastewaters theoretically may be used as the substrates of MECs for $\mathrm{H}_{2}$ production (Table 3). Furthermore, different food processing wastewaters from food processing plants offer different individual $\mathrm{H}_{2}$ production values, which are demonstrated as follows.

Table 3 Design properties and performances of the MECs fed with food processing wastewater

\begin{tabular}{|c|c|c|c|c|c|c|c|c|c|c|c|c|c|}
\hline $\begin{array}{l}\text { Actual wastewater } \\
\text { types }\end{array}$ & $\begin{array}{l}\text { MEC } \\
\text { system }\end{array}$ & $\begin{array}{l}\text { Operation } \\
\text { mode }\end{array}$ & $\begin{array}{l}\text { Anode } \\
\text { material }\end{array}$ & $\begin{array}{l}\text { Cathode } \\
\text { material }\end{array}$ & $\begin{array}{c}\text { MEC } \\
\text { Volume } \\
\text { /mL }\end{array}$ & Separator & $\begin{array}{l}\text { Catalyst } \\
\text { in } \\
\text { cathode }\end{array}$ & $\begin{array}{l}\mathrm{BOD}_{5} / \\
\mathrm{COD}\end{array}$ & $\begin{array}{l}\text { TCOD } \\
\text { removal }\end{array}$ & $\begin{array}{c}\mathrm{H}_{2} \text { production } \\
\text { Rate } \\
/ \mathrm{L} \mathrm{H}_{2} \cdot \mathrm{L}^{-1} \cdot \mathrm{d}^{-1}\end{array}$ & $\begin{array}{l}C_{E} \\
/ \%\end{array}$ & $\begin{array}{l}\eta_{E+S} \\
/ \%\end{array}$ & Ref. \\
\hline Potato wastewater & Single & Batch & $\begin{array}{l}\text { Graphite } \\
\text { fiber brush }\end{array}$ & Carbon cloth & 28 & NO & Pt & - & $79 \%$ & 0.74 & 80 & - & [69] \\
\hline $\begin{array}{l}\text { Food processing } \\
\text { wastewater }\end{array}$ & Single & Batch & $\begin{array}{l}\text { Graphite fiber } \\
\text { brushes }\end{array}$ & Carbon cloth & 336 & NO & $\begin{array}{l}\mathrm{SS} ; \\
\mathrm{MoS}_{2} ; \\
\mathrm{Pt}\end{array}$ & $0.25-0.62$ & $\begin{array}{l}49 \% \\
56 \% \\
67 \%\end{array}$ & $\begin{array}{c}0.103 \\
0.146 \\
0.312\end{array}$ & $\begin{array}{c}29 \\
26 \\
35\end{array}$ & - & [75] \\
\hline Winery wastewater & Single & $\begin{array}{l}\text { Continuous/ } \\
\text { Batch }\end{array}$ & $\begin{array}{l}\text { Graphite } \\
\text { fiber brush }\end{array}$ & $\begin{array}{c}\text { SS mesh/ } \\
\text { Carbon cloth }\end{array}$ & $1000000 / 28$ & NO & $-/ \mathrm{Pt}$ & - & $62 \% / 47 \%$ & $0.07 / 0.17$ & $-/ 50$ & $78^{-/}\left(\eta_{E}\right)$ & [76] \\
\hline Brewery wastewater & Single & Batch & Carbon brush & Nickel foam & 25 & NO & $\mathrm{Pt}$ & - & $87-94 \%$ & 2.12 & 66 & $170\left(\eta_{E}\right)$ & {$[28]$} \\
\hline $\begin{array}{l}\text { Cheese whey from a } \\
\text { cheese facility }\end{array}$ & Single & Continuous & Carbon felt & $\begin{array}{c}\text { Gas diffusion } \\
\text { electrode }\end{array}$ & 100 & NO & $\mathrm{Ni}$ & $0.4-0.8$ & $>80 \%$ & $\sim 0.8$ & - & - & {$[77]$} \\
\hline $\begin{array}{l}\text { Molasses } \\
\text { wastewater }\end{array}$ & Single & Batch & $\begin{array}{c}\text { Graphite-fiber } \\
\text { brush }\end{array}$ & $\begin{array}{l}\text { Carbon } \\
\text { cloth }\end{array}$ & 25 & NO & Pt & - & - & $1.82-2.27$ & $\begin{array}{l}93- \\
95\end{array}$ & $\begin{array}{c}220- \\
269\left(\eta_{E}\right)\end{array}$ & {$[78]$} \\
\hline
\end{tabular}

Note: "TCOD" is total chemical oxygen demand; "SCOD" stands for soluble chemical oxygen demand; " $C_{E}$ " stands for columbic efficiency; " $\eta_{E+S}$ " stands for energy efficiency based on electricity and substrates; " $\eta_{E}$ " stands for energy efficiency based on electricity; "SS" stands for stainless steel.

\subsubsection{Brewery wastewater and winery wastewater}

Brewery wastewater mainly consists of sugars, proteins, organic acids, amino acids, alcohols, and vitamins. The ratio of $\mathrm{BOD}_{5}$ to TCOD is $0.57-0.73$ (the $\mathrm{BOD}_{5}$ of $1285-1540 \mathrm{mg} / \mathrm{L}$; the TCOD of 2106-2250 mg/L). Further, this type of wastewater has the following characteristics: its $\mathrm{pH}$ and conductivity are 6.7 and $1.8 \mathrm{mS} / \mathrm{cm}$, respectively ${ }^{[79]}$.

When brewery wastewater was previously used as the substrate of MECs for $\mathrm{H}_{2}$ production while using the cathode catalyst of $\mathrm{NiFe}$ layered double hydroxide, a high-efficiency $\mathrm{H}_{2}$ production rate $(2.01-2.12 \mathrm{~L} / \mathrm{L} \cdot \mathrm{d})$ could be achieved ${ }^{[28]}$. In addition, it was also designed to produce methane in continuous, tubular up-flow membrane-free MECs with the cathode of $\mathrm{Ni}$ catalysis at an $\mathrm{E}_{\mathrm{ap}}$ of $0.8 \mathrm{~V}$. In this setup, better performances were obtained with a TCOD removal efficiency of $85 \%{ }^{[79]}$.

Winery wastewater has similar properties to that of brewery wastewater. When it was chosen as the feed of MECs, $\mathrm{H}_{2}$ production rate and $\eta_{\mathrm{E}}$ were $0.17 \mathrm{~L} / \mathrm{L} \cdot \mathrm{d}$ and $78 \%$ (based on electrical energy) were obtained at an $\mathrm{E}_{\mathrm{ap}}$ of $0.9 \mathrm{~V}^{[80]}$. Here, compared with MFC treatment of winery wastewater, although the TCOD removal efficiency in the MECs was a little lower than it was in the MFCs (47\% vs. 65\%), $\mathrm{C}_{\mathrm{E}}$ was obviously higher than it in MFCs $(50 \% \text { vs. } 18 \%)^{[80]}$. For scale-up from laboratory tests, a pilot-scale single-chamber MEC of $1000 \mathrm{~L}$ fed with real winery wastewater under continuous mode showed a comparable SCOD removal $(62 \%)$, but the $\mathrm{H}_{2}$ production rate and the $\mathrm{H}_{2}$ content in the product gases were only $0.07 \mathrm{~L} / \mathrm{L} \cdot \mathrm{d}$ and $14 \%$, respectively ${ }^{[76]}$. Therefore, the performances of pilot-scale MEC reactors need to be improved further via optimizing the critical factors like the experimental temperature, initial $\mathrm{pH}, \mathrm{E}_{\mathrm{ap}}$, etc.

\subsubsection{Dairy wastewater}

Milk residuals, milk fats and whey particles are all present in dairy wastewater. Further, it was reported that dairy wastewater has a $\mathrm{pH}$ of 6.2 and a high TCOD concentration $(5-50 \mathrm{~g} / \mathrm{L})^{[81]}$. Before investigating real milk wastewater from the dairy industry, firstly synthetic dairy wastewater by commercial powder milk was chosen as the substrate of single-chamber MEC for $\mathrm{H}_{2}$ production without adding any methanogenesis inhibitors. After more than three-months of long-term operation, stable $\mathrm{H}_{2}$ production, $C_{E}$, and TCOD removal were obtained at $0.8 \mathrm{~V}^{[82]}$. As for the treatment of real dairy wastewater, up to now, although only photo-biological treatment processes have been conducted for this type of feedstock $^{[81]}$, it could be predicted that if it was used as the substrate for MECs, ideal performances could be achieved.

2.4.3 Potato wastewater

Potato wastewater was reported to have a SCOD of $0.69 \mathrm{~g} / \mathrm{L}^{[69]}$ When synthetic potato wastewater simulated with starch (analytical grade reactant) was used as the substrates of a MEC, the TCOD removal was up to $70 \%$. However, $\mathrm{H}_{2}$ was not detected, even if the retention time of $\mathrm{H}_{2}$ was shortened by continuous nitrogen sparging $^{[82]}$. Interestingly, when 4-times diluted potato wastewater without the addition of a buffer was used as the substrate for single-chamber cubic MECs, better performances were obtained with a TCOD removal of $79 \%$ and a $C_{E}$ of $80 \%{ }^{[69]}$.

\subsubsection{Molasses wastewater}

Molasses wastewater is a by-product during sugar beet process, which has a high-concentration organics (65000-130000 mg/L) and mineral salts ${ }^{[83]}$. Furthermore, this nutrient-rich wastewater contains mainly sugar, protein, and vitamins $(70 \%$ of solid substance $)^{[78]}$. This type of wastewater can be used for producing 
ethanol and amino acids ${ }^{[83]}$, but actually its quantity is too large to be treated. Therefore, its potential application should be explored further. When this molasses wastewater was treated via MECs with the inclusion of a Pt catalyst in the cathode, the $C_{E}$ was $93 \%$ at an $\mathrm{E}_{\mathrm{ap}}$ of $0.6 \mathrm{~V}$ at $25^{\circ} \mathrm{C}^{[78]}$. In addition, the $\mathrm{H}_{2}$ content in the gases could be enhanced from $34.6 \%$ to $48.2 \%$ through lowering the temperature from $25^{\circ} \mathrm{C}$ to $9^{\circ} \mathrm{C}$, due to the fact that methane production at lower temperatures was successfully inhibited ${ }^{[78]}$.

Table 4 Design properties and performances of the MECs fed with fermentation effluent

\begin{tabular}{|c|c|c|c|c|c|c|c|c|c|c|c|c|c|}
\hline $\begin{array}{l}\text { Actual wastewater } \\
\text { types }\end{array}$ & $\begin{array}{l}\text { MEC } \\
\text { system }\end{array}$ & $\begin{array}{l}\text { Operation } \\
\text { mode }\end{array}$ & Anode material & $\begin{array}{l}\text { Cathode } \\
\text { material }\end{array}$ & $\begin{array}{c}\text { MEC } \\
\text { Volume } \\
/ \mathrm{mL}\end{array}$ & Separator & $\begin{array}{l}\text { Catalyst } \\
\text { in } \\
\text { cathode }\end{array}$ & $\begin{array}{l}\mathrm{BOD}_{5} / \\
\mathrm{COD}\end{array}$ & $\begin{array}{l}\text { TCOD } \\
\text { removal }\end{array}$ & $\begin{array}{c}\mathrm{H}_{2} \text { production } \\
\text { rate } \\
/ \mathrm{L} \mathrm{H}_{2} \cdot \mathrm{L}^{-1} \cdot \mathrm{d}^{-1}\end{array}$ & $\begin{array}{l}C_{E} \\
/ \%\end{array}$ & $\begin{array}{l}\eta_{E+S} \\
/ \%\end{array}$ & Ref. \\
\hline $\begin{array}{l}\text { Lignocellulose } \\
\text { effluent }\end{array}$ & Single & Continuous & $\begin{array}{l}\text { Graphite } \\
\text { fiber brush }\end{array}$ & Carbon cloth & 28 & $\mathrm{NO}$ & $\mathrm{Pt} / \mathrm{C}$ & - & $65 \%$ & 1 & 110 & 61 & [89] \\
\hline Fermentation effluent & Single & Continuous & $\begin{array}{l}\text { Carbon fiber } \\
\text { brush }\end{array}$ & Carbon cloth & 72 & NO & $\mathrm{Pt}$ & - & $64 \%$ & 0.48 & 58 & 23 & {$[90]$} \\
\hline Fermentation effluent & Single & Batch & Graphite brush & Carbon cloth & 26 & $\mathrm{NO}$ & $\mathrm{Pt}$ & - & $\sim 38.5 \%$ & 1.41 & 87 & 70 & [91] \\
\hline $\begin{array}{l}\text { Brewery wastewater } \\
\text { fermentation effluent }\end{array}$ & Single & Batch & Carbon brush & $\begin{array}{l}\text { Nickel } \\
\text { foam }\end{array}$ & 25 & NO & NiFe LDH & - & $87-94 \%$ & 2.11 & 82 & $190\left(\eta_{E}\right)$ & {$[28]$} \\
\hline Effluent from an $\mathrm{ABR}$ & Single & Batch & Carbon cloth & SS mesh & 85 & NO & $\mathrm{Ni}$ & - & $99 \%$ & 1.31 & - & $139\left(\eta_{E}\right)$ & [92] \\
\hline Effluent from WWTP & Dual & Batch & Graphite plates & SS plates & 60000 & PEM & NO & - & $67 \%$ & - & 11 & - & [17] \\
\hline
\end{tabular}

Note: "TCOD" stands for total chemical oxygen demand; " $C_{E}$ " stands for columbic efficiency; " $\eta_{E+S}$ " stands for energy efficiency based on electricity and substrates; " $\eta_{E}$ " stands for energy efficiency based on electricity; "PEM" stands for proton exchange membrane; "LDH" stands for layered double hydroxide; "SS" stands for stainless steel; "ABR" stands for anaerobic baffled reactor; "WWTP” is wastewater treatment plant.

\subsection{Fermentation effluent}

There are a few methods to produce $\mathrm{H}_{2}$ from lignocellulosic biomass, such as bio-photolysis, photo-fermentation, and dark-fermentation $(\mathrm{DF})^{[84]}$. Among these routes, DF showed the highest $\mathrm{H}_{2}$ yield in practice ${ }^{[85]}$. However, compared with theoretical values, the $\mathrm{H}_{2}$ yield was still very low because the fermentation end-products like acetic, formic, succinic, lactic acids, etc. cannot be transformed to $\mathrm{H}_{2}$ via fermentative microorganisms further ${ }^{[86]}$. Thus, these residual matters remained in the fermentation effluent. The original real fermentation effluent from the cornstalk contained total VFAs $(8021.2 \mathrm{mg} / \mathrm{L})$, COD value (11986.4 mg COD/L), HAc (4121.5 mg/L), HBu (3208.1 mg/L), $\operatorname{HPr}(88.8 \mathrm{mg} / \mathrm{L})$, Ethanol $(602.8 \mathrm{mg} / \mathrm{L})$, etc. ${ }^{[87]}$.

However, these organic matters in the fermentation effluent have proven to be ideal substrates for MECs (Table 4). Here, it was confirmed that the acetate and the butyrate were demonstrated to be easily degraded by exoelectrogens in MECs, and the propionate was recalcitrant to degradation ${ }^{[29]}$. The accumulation of acetic acid during the fermentation stage can improve the $\mathrm{H}_{2}$ production rate and TCOD removal efficiency for the MECs. Note that the component of fermentation pretreatment wastewater could have important effects on MEC performances. The MEC treatment for fermentation pretreatment wastewater (gradient utilization of the substrates) had several benefits: it improved the effluent quality and enhanced $\mathrm{H}_{2}$ production. In theory, the integration of fermentation and MEC can increase the $\mathrm{H}_{2}$ yield to $12 \mathrm{~mol} \mathrm{H}_{2} / \mathrm{mol} \mathrm{glucose}^{[88]}$.

In practice, when dark fermentation effluent was used as the substrates of MECs, a $\mathrm{H}_{2}$ production and $\mathrm{C}_{\mathrm{E}}$ were obtained $(1 \mathrm{~L} / \mathrm{L} \cdot \mathrm{d}$ and $110 \%)$ at an $\mathrm{E}_{\text {ap }}$ of $0.5 \mathrm{~V}^{[89]}$. In fact, overall $\mathrm{H}_{2}$ production via MECs fed with cellulose fermentation effluent increased by $41 \%$ in comparison to dark fermentation alone ${ }^{[90]}$. When diluted fermentation liquid was used as the substrates, the SCOD removal was higher than that of the original fermentation liquid $(60 \%$ vs. $50 \%)$ in the $\mathrm{MEC}^{[93]}$. In addition, fermentation effluent $\mathrm{pH}$ has an important effect on MEC performances. One study confirmed that MECs fed with raw ethanol-type fermentation effluent (initial $\mathrm{pH}$ 4.5-4.6) had a lower $\mathrm{H}_{2}$ production rate $(0.04 \mathrm{~L} / \mathrm{L} \cdot \mathrm{d})$ compared to that fed with the buffered ethanol-type of fermentation effluent $(1.41 \mathrm{~L} / \mathrm{L} \cdot \mathrm{d})$ at an $\mathrm{E}_{\mathrm{ap}}$ of $0.6 \mathrm{~V}^{[91]}$. If the fermentation stage was optimized in an anaerobic baffled reactor before the MEC process, a higher $\mathrm{H}_{2}$ production rate $(1.31 \mathrm{~L} / \mathrm{L} \cdot \mathrm{d})$ and a higher TCOD removal efficiency $(99.0 \%)$ could be obtained in a single-chamber MEC due to the acetic acid-rich fermentation effluent ${ }^{[92]}$. Thus, dark fermentation can be considered as a pretreatment path for biomass into $\mathrm{H}_{2}$ via MECs.

\section{Challenges and Future Perspectives}

MEC technology has been demonstrated to be more preferable than that of bioelectricity generation (the MFC) for treating actual complex wastewaters ${ }^{[94]}$. However, this wastewater treatment technology is still in the infancy stages of development. As an emerging and versatile technology, MECs integrate microbial interaction processes and electrochemical processes, so the limiting factors of the system are complex and hard to identify ${ }^{[94]}$. The important challenges and future perspectives are addressed towards the practical application of MEC technology.

\subsection{Complexity of actual wastewater}

The treatment of actual wastewater via MECs is restricted by the water quality features such as a lower conductivity, unsuited alkalinity to catalysts, the toxicity of some compounds to anodic microorganisms, and the variation of the organic loading rate ${ }^{[88]}$. The characteristics of real complex wastewaters have great effects on the performances of $\mathrm{MECs}^{[75]}$. In particular, lower conductivity and unsuitable alkalinity to catalysts can lead to considerable Ohmic losses and high $\mathrm{pH}$ gradients, respectively. MECs undergo an electrochemical process and a microbial catalytic process, so the microorganism on the anode requires ambient conditions to maintain bioactivity. Generally speaking, when real wastewaters were fed to MECs, electrochemical performances were reduced (e.g. $C_{E}$ ) compared with simple, easily biodegradable, or definite substrates. The reason for this may be due to the presence of competitive consumption of the substrates by the methanogenesis pathway and not being able to completely degrade the complex organic matters in the real wastewater via electrochemically active microorganisms in the anode ${ }^{[95]}$. Thus, one major challenge is improving the $C_{E}$ and $\mathrm{H}_{2}$ production rate in future practical applications. Now, many studies focused on actual wastewater treatment via MECs are still only conducted at the bench scale ${ }^{[96]}$. Now, there are few full-scale treatment plants 
for recalcitrant wastewaters, some challenges still need to be overcome even if in small-scale or lab-scale studies like the complexity of actual wastewaters, inhibition of recalcitrant organics in the wastewaters for electro-active bacteria, instability of $\mathrm{H}_{2}$ production, cultivation and modification of robust microorganisms, etc. However, MEC treatment of complex wastewaters had great potential in practical application due to its many advantages as described previously.

To better solve this problem, several approaches could be attempted, such as comprehensively investigating the complexity of different real wastewaters via the advanced equipment, optimizing MEC system configurations, acclimating the higher electro-active bacteria, studying the mechanisms and kinetics of electron transfer in depth, choosing cathode catalysts of high-efficiency to decrease the over-potential of electrochemical reactions, and exploring electrode materials of high performances ${ }^{[97]}$. In addition, it is worthwhile to explore in depth the degradation pathways of substances like heterocyclic compounds from actual wastewaters, which mainly depend on the electron acceptors and electron donors $^{[98]}$. Besides the aforementioned approaches, it is also essential to investigate the degradation of the final products, because sometimes the final products were more toxic to the anode bacteria than the parent compounds themselves.

\subsection{Instability of $\mathbf{H}_{2}$ production}

$\mathrm{H}_{2}$ production performance is a comprehensive result of different $\mathrm{E}_{\mathrm{ap}}, \mathrm{pH}$, temperature, hydraulic retention times (HRTs), substrate types, electrode materials, substrate concentration, anode inoculum, cathode catalyst, the start-up mode, the running mode, etc. In single-chamber MECs, the instability of $\mathrm{H}_{2}$ production is probably due to the competitive consumption of the substrates by methanogens in the MEC anode. To restrain methanogen metabolism, some methods could be adopted like exposing the cathode chamber to air periodically, lowering the $\mathrm{pH}^{[20]}$, designing shorter retention times, heat pretreatment of the inoculum, and adding inhibitors to methanogens growth (e.g. 2-bromoethanesulfonate ${ }^{[21]}$. However, methanogen growth cannot be entirely inhibited. In dual-chamber MECs, except for $\mathrm{CH}_{4}$ diffusion though membranes, another key reason for this may be mass transfer resistance, including proton transfer resistance though the membrane and electron transfer resistance though exoelectrogenic bacteria. In addition, the instability of the operation process leads to unstable $\mathrm{H}_{2}$ production. Thus, the enhancement of $\mathrm{H}_{2}$ purity is still a great challenge for future MEC practical applications, which needs to be further explored though breakthrough optimization in reactor configurations, operation parameters, and the electrode materials.

\subsection{Robust microorganisms}

It is known that electron transfer activity of exoelectrogenic bacteria is very important for $\mathrm{H}_{2}$ production in the MEC. Many previous cases used the mixed bacteria as the initial inoculum of the MEC from the previous MFC/MEC reactor, fresh municipal/domestic wastewater, or activated sludge. The cultivation or enrichment of exoelectrogenic bacteria from the mixture bacteria needs a long time ranging from one month to several months. In MEC, microbial community was consisted of fermentative bacteria (like Paludibacter, Enterococcaceae, Petrimonas), exoelectrogenic bacteria exoelectrogens (like Geobacter, Geoalkalibacter), and a little other bacteria (like Acetobacterium $)^{[99]}$, when the substrates were supplied, firstly fermentative bacteria degraded various organics (like sugar, carbohydrates, protein) into organic acids (like acetate, butyrate, and propionate), then exoelectrogenic bacteria produced electricity by these organic acids ${ }^{[100]}$. However, there were substrate and electron competition between fermentative bacteria and exoelectrogens. If pure bacteria like $S$. oneidensis $M R-1$ was used for the inoculum, the total $\mathrm{H}_{2}$ output and $\mathrm{H}_{2}$ purity would be improved greatly, because pure bacteria would prevent the consumption of $\mathrm{H}_{2}$ and methane formation from other bacteria like fermentative bacteria, methanogens. Further, pure bacteria are expensive and make the cost higher than that when using the mixed bacteria in the actual application. In addition, considering the inhibition of substances in actual high-strength wastewaters, the improvement of the microbial consortia tolerance against these substances may be necessary and important. Thus, the identification of new microbes or genetic modification of microbes is a promising aspect for actual wastewater treatment via METs ${ }^{[101]}$.

\subsection{Effect of membrane on two-chamber MEC}

In two-chamber MEC, the function of membrane was mainly in order to improve hydrogen purity, alleviate hydrogen consumption by anodic microbes, and finally increase energy recovery of substrates ${ }^{[102]}$. Up to now, various membranes were used in MECs. However, the substantial internal resistance from membranes during proton transfer cannot be ignored. And their selectivity for protons were very limited, it has still no membranes only allowed protons to pass through. In addition, membrane fouling was a serious problem for long-term stable operation of MEC, which had great effect on matter transfer and desired product generation (like hydrogen). Thus membranes need to be modified and cleaned, but the cost was high ${ }^{[103]}$. In the future, for decreasing the membrane fouling, some other low-cost methods could be tried such as reactor structure optimization, proper choice of important parameters, new membrane development, etc.

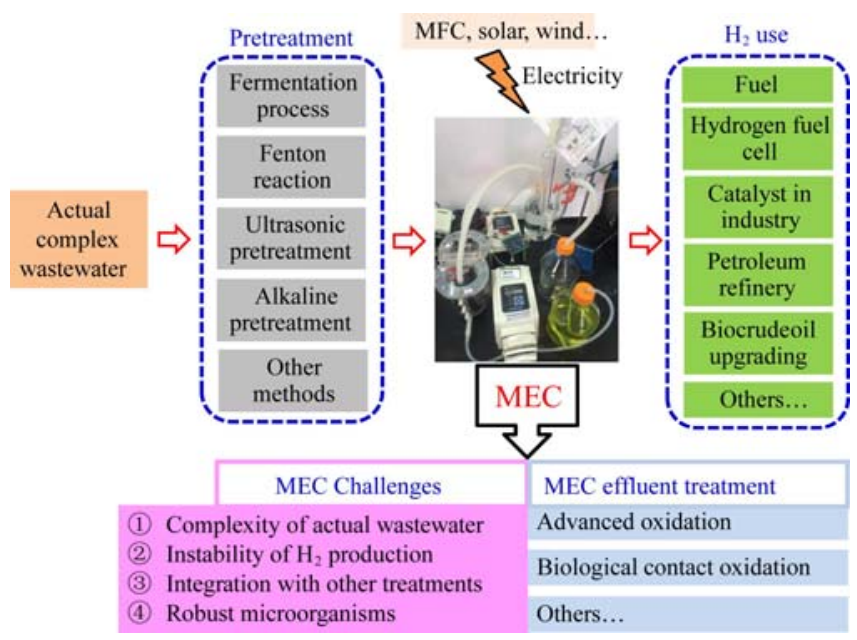

Figure 2 Integration of MEC with other treatment processes

\subsection{Integration of MEC with other treatment processes}

The combination of MECs and other technologies has been suggested to enhance the treatment of wastewaters (Figure 2). For instance, a fermentation- MEC integrated process has been previously proposed, since the fermentation process is beneficial for high-strength wastewater with complex organic compounds, while the fermentation effluent containing VFAs was regarded as the ideal substrate of MECs for further $\mathrm{H}_{2}$ recovery. Furthermore, some typical physicochemical technologies such as ultrasonic pretreatment, alkaline pretreatment, and Fenton reactions, could be adapted as pretreatment methods before MECs for toxic compound removal to relieve the inhibition of anode respiring bacteria. In addition, the MFC-MEC integrated system was invented to reduce 
the cost of power supply for MECs by timely use of the renewable electricity generated from MFCs. Recently, the usage of MFC-MEC studies have been more focused on the treatment and selective metal recovery from heavy metal contaminated wastewater, taking advantage of the difference of the redox potentials at the cathodes.

Moreover, the combination of MECs with other treatment processes has also been suggested for timely use of the MEC products (like $\mathrm{H}_{2} \mathrm{O}_{2}, \mathrm{H}_{2}$ ) as the reagents of the following process, which could cut down the storage cost and transportation cost of MEC products. For example, The MEC-Fenton integrated process has been proposed to address this need, by timely use of the $\mathrm{H}_{2} \mathrm{O}_{2}$ production from MECs to react with Fenton's reagent to form hydroxyradical for refractory pollutant removal. Another example is the MEC-HTL integrated process, which has been recently proposed, in which HTL is used for bio-crude oil production from wet organic waste, while the $\mathrm{H}_{2}$ recovered during the treatment of PHWW via MECs, could be used for onsite bio-crude oil upgrading. Overall, the combination of several treatment processes has great potential for thorough treatment of actual recalcitrant wastewaters.

\section{Conclusions}

This review introduced the characteristics of various complicated wastewater, and focused on analyzing and summarizing MEC development for wastewater treatment. The performances of MECs mainly depend on the ingredients of individual wastewaters, especially the content of recalcitrant compounds in the wastewaters. Up to now, it has been proven that MEC technology efficiently treats PHWW, pyrolysis wastewater, de-oiled refinery wastewater, landfill leachate, animal manure wastewater, brewery wastewater, winery wastewater, dairy wastewater, potato wastewater, molasses wastewater, etc. MEC performances for treating actual complex wastewaters and producing $\mathrm{H}_{2}$ can be optimized through operation parameters, electrode materials, catalyst materials, etc. However, some niches and challenges such as the complexity of actual wastewaters, inhibition of recalcitrant organics in the wastewaters for electro-active bacteria, instability of $\mathrm{H}_{2}$ production, cultivation and modification of robust microorganisms, etc., have to be overcome one by one. Except for the technical feasibility, both environmental feasibility and economic feasibility also need to meet social requirements, which could be met by controlling the investment cost and increasing the $\mathrm{H}_{2}$ production rate. Until all difficulties are solved one by one, practical commercial applications cannot be realized successfully in the future.

\section{Acknowledgements}

This work was supported by China Postdoctoral Science Foundation (2018M641295), China Agriculture Research System (CARS-02), and National Natural Science Foundation of China (51561145013).

\section{Nomenclature}

\begin{tabular}{ll}
\hline MEC & Microbial Electrolysis Cell \\
MFC & Microbial Fuel Cell \\
AD & Anaerobic Digestion \\
COD & Chemical Oxygen Demand \\
TCOD & Total Chemical Oxygen Demand \\
TOC & Total Organic Carbon \\
\hline
\end{tabular}

\begin{tabular}{|c|c|}
\hline VFAs & Volatile Fatty Acids \\
\hline TS & Total Solid \\
\hline VS & Volatile Solid \\
\hline $\mathrm{C}_{\mathrm{E}}$ & Coulombic Efficiency \\
\hline $\mathrm{\eta}_{\mathrm{E}}$ & Energy Efficiency (Electricity) \\
\hline PHWW & Post-hydrothermal Liquefaction Wastewater \\
\hline AEM & Anion Exchange Membrane \\
\hline CEM & Cation Exchange Membrane \\
\hline PEM & Proton Exchange Membrane \\
\hline BPM & Bipolar Membrane \\
\hline $\mathrm{CMM}$ & Charged Mosaic Membrane \\
\hline UM HTL & Ultrafiltration Membrane Hydrothermal Liquefaction \\
\hline SCOD & Solluted Chemical Oxygen Demand \\
\hline BOD & Biochemical Oxygen Demand \\
\hline 5-HMF & 5-Hydroxymethyl Furfural \\
\hline HRTs & Hydraulic Retention Times \\
\hline $\mathrm{E}_{\mathrm{ap}}$ & Applied Voltage \\
\hline PBS & Phosphate Buffer Saline \\
\hline
\end{tabular}

\section{[References]}

[1] Pandey P, Shinde V N, Deopurkar R L, Kale S P, Patil S A, Pant D. Recent advances in the use of different substrates in microbial fuel cells toward wastewater treatment and simultaneous energy recovery. Applied Energy, 2016; 168: 706-723.

[2] Qureshi A S, Hussain M I, Ismail S, Khan Q M. Evaluating heavy metal accumulation and potential health risks in vegetables irrigated with treated wastewater. Chemosphere, 2016; 163: 54-61.

[3] Zeppilli M, Simoni M, Paiano P, Majone M. Two-side cathode microbial electrolysis cell for nutrients recovery and biogas upgrading. Chemical Engineering Journal, 2019.

[4] Gan K, Mou X, Xu Y, Wang H. Application of ozonated piggery wastewater for cultivation of oil-rich Chlorella pyrenoidosa. Bioresource Technology, 2014; 171: 285-290.

[5] Iskander S M, Brazil B, Novak J T, He Z. Resource recovery from landfill leachate using bioelectrochemical systems: Opportunities, challenges, and perspectives. Bioresource Technology, 2016; 201: 347-354.

[6] Katuri K P, Ali M, Saikaly P E. The role of microbial electrolysis cell in urban wastewater treatment: integration options, challenges, and prospects. Current Opinion in Biotechnology, 2019(57): 101-110.

[7] Ghosh S, Dairkee U K, Chowdhury R, Bhattacharya P. Hydrogen from food processing wastes via photofermentation using purple non-sulfur bacteria (PNSB): A review. Energy Conversion and Management, 2016.

[8] Ivanov I, Ren L, Siegert M, Logan B E. A quantitative method to evaluate microbial electrolysis cell effectiveness for energy recovery and wastewater treatment. International Journal of Hydrogen Energy, 2013; 38(30): 13135-13142.

[9] Lusk B G, Colin A, Parameswaran P, Rittmann B E, Torres C I. Simultaneous fermentation of cellulose and current production with an enriched mixed culture of thermophilic bacteria in a microbial electrolysis cell. Microbial Biotechnology, 2018; 11(1): 63-73.

[10] Ullery M L, Logan B E. Anode acclimation methods and their impact on microbial electrolysis cells treating fermentation effluent. International Journal of Hydrogen Energy, 2015; 40(21): 6782-6791.

[11] Jayabalan T, Matheswaran M, Naina Mohammed S. Biohydrogen production from sugar industry effluents using nickel based electrode materials in microbial electrolysis cell. International Journal of Hydrogen Energy, 2019; 44(32): 17381-17388.

[12] Khan M Z, Nizami A S, Rehan M, Ouda O K M, Sultana S, Ismail I M, et al. Microbial electrolysis cells for hydrogen production and urban wastewater treatment: A case study of Saudi Arabia. Applied Energy, 2017; 185: 410-420.

[13] Guo X, Liu J, Xiao B. Bioelectrochemical enhancement of hydrogen and methane production from the anaerobic digestion of sewage sludge in single-chamber membrane-free microbial electrolysis cells. International Journal of Hydrogen Energy, 2013; 38(3): 1342-1347.

[14] Jwa E, Yun Y, Kim H, Jeong N, Park S, Nam J. Domestic wastewater 
treatment in a tubular microbial electrolysis cell with a membrane electrode assembly. International Journal of Hydrogen Energy, 2019; 44(2): 652-660.

[15] Mahmoud M, Parameswaran P, Torres C I, Rittmann B E. Relieving the fermentation inhibition enables high electron recovery from landfill leachate in a microbial electrolysis cell. RSC Adv., 2016; 6(8): 6658-6664.

[16] Ye Y, Logan B E. The importance of $\mathrm{OH}-$ transport through anion exchange membrane in microbial electrolysis cells. International Journal of Hydrogen Energy, 2018; 43(5): 2645-2653.

[17] Brown R K, Harnisch F, Wirth S, Wahlandt H, Dockhorn T, Dichtl N, et al. Evaluating the effects of scaling up on the performance of bioelectrochemical systems using a technical scale microbial electrolysis cell. Bioresource Technology, 2014; 163: 206-213.

[18] Hua T, Li S, Li F, Zhou Q, Ondon B S. Microbial electrolysis cell as an emerging versatile technology: a review on its potential application, advance and challenge. Journal of Chemical Technology \& Biotechnology, 2019; 94(6): 1697-1711.

[19] Kadier A, Kalil M S, Chandrasekhar K, Mohanakrishna G, Saratale G D, Saratale R G, et al. Surpassing the current limitations of h igh purity $\mathrm{H}_{2}$ production in microbial electrolysis cell (MECs): Strategies for inhibiting growth of methanogens. Bioelectrochemistry, 2017.

[20] Rathinam N K, Bibra M, Salem D R, Sani R K. Thermophiles for biohydrogen production in microbial electrolytic cells. Bioresource Technology, 2019.

[21] Park S, Rhee C, Shin S G, Shin J, Mohamed H O, Choi Y, et al. Methanogenesis stimulation and inhibition for the production of different target electrobiofuels in microbial electrolysis cells through an on-demand control strategy using the coenzyme $\mathrm{M}$ and 2-bromoethanesulfonate. Environment International, 2019; 131: 105006.

[22] Rozenfeld S, Ouaknin Hirsch L, Gandu B, Farber R, Schechter A, Cahan R. Improvement of microbial electrolysis cell activity by using anode based on combined plasma-pretreated carbon cloth and stainless steel. Energies, 2019; 12(10): 1968

[23] Ren L, Siegert M, Ivanov I, Pisciotta J M, Logan B E. Treatability studies on different refinery wastewater samples using high-throughput microbial electrolysis cells (MECs). Bioresource Technology, 2013; 136(1): 322-328.

[24] Heidrich E S, Edwards S R, Dolfing J, Cotterill S E, Curtis T P. Performance of a pilot scale microbial electrolysis cell fed on domestic wastewater at ambient temperatures for a 12 month period. Bioresource Technology, 2014; 173(1): 87-95.

[25] Kuntke P, Sleutels T H J A, Saakes M, Buisman C J N. Hydrogen production and ammonium recovery from urine by a microbial electrolysis cell. International Journal of Hydrogen Energy, 2014; 39(10): 4771-4778.

[26] Jia Y H, Choi J Y, Ryu J H, Kim C H, Lee W K, Tran H T, et al. Hydrogen production from wastewater using a microbial electrolysis cell. Korean Journal of Chemical Engineering, 2010; 27(6): 1854-1859.

[27] Kargi F, Catalkaya E C, Uzuncar S. Hydrogen gas production from waste anaerobic sludge by electrohydrolysis: Effects of applied DC voltage. International Journal of Hydrogen Energy, 2011; 36(3): 2049-2056.

[28] Lu L, Hou D, Fang Y, Huang Y, Ren Z J. Nickel based catalysts for highly efficient $\mathrm{H}_{2}$ evolution from wastewater in microbial electrolysis cells. Electrochimica Acta, 2016; 206: 381-387.

[29] Escapa A, Lobato A, A D M G, N A M. Hydrogen production and COD elimination rate in a continuous microbial electrolysis cell: the influence of hydraulic retention time and applied voltage. Environmental Progress \& Sustainable Energy, 2013; 32(2): 263-268.

[30] Liu H, Hu H, Chignell J, Fan Y. Microbial electrolysis: novel technology for hydrogen production from biomass. Biofuels, 2010; 1(1): 129-142.

[31] Heidrich E S, Dolfing J, Scott K, Edwards S R, Jones C, Curtis T P. Production of hydrogen from domestic wastewater in a pilot-scale microbial electrolysis cell. Applied Microbiology and Biotechnology, 2013; 97(15): 6979-6989.

[32] Yahya A M, Hussain M A, Abdul Wahab A K. Modeling, optimization, and control of microbial electrolysis cells in a fed-batch reactor for production of renewable biohydrogen gas. International Journal of Energy Research, 2015; 39(4): 557-572.

[33] Jafary T, Daud W R W, Ghasemi M, Kim B H, Carmona-Martínez A A, Bakar $\mathrm{M} \mathrm{H}$ A, et al. A comprehensive study on development of a biocathode for cleaner production of hydrogen in a microbial electrolysis cell. Journal of Cleaner Production, 2017; 164: 1135-1144.

[34] Zou S, Qin M, Moreau Y, He Z. Nutrient-energy-water recovery from synthetic sidestream centrate using a microbial electrolysis cell - forward osmosis hybrid system. Journal of Cleaner Production, 2017; 154: 16-25.

[35] Pepè Sciarria T, Vacca G, Tambone F, Trombino L, Adani F. Nutrient recovery and energy production from digestate using microbial electrochemical technologies (METs). Journal of Cleaner Production, 2019; 208: 1022-1029.

[36] Jafary T, Daud W R W, Ghasemi M, Kim B H, Bakar M H A, Jahim J M, et al. Assessment of recirculation batch mode of operation in bioelectrochemical system; a way forward for cleaner production of energy and waste treatment. Journal of Cleaner Production, 2017; 142: 2544-2555.

[37] Jiang Y, Zeng R J. Bidirectional extracellular electron transfers of electrode-biofilm: Mechanism and application. Bioresource Technology, 2019; 271: 439-448.

[38] Wrana N, Sparling R, Cicek N, Levin D B. Hydrogen gas production in a microbial electrolysis cell by electrohydrogenesis. Journal of Cleaner Production, 2010; 18: S105-S111.

[39] Yavuz Y, Koparal A S, öğütveren Ü B. Treatment of petroleum refinery wastewater by electrochemical methods. Desalination, 2010; 258(1-3): 201-205.

[40] Shen R, Liu Z, He Y, Zhang Y, Lu J, Zhu Z, et al. Microbial electrolysis cell to treat hydrothermal liquefied wastewater from cornstalk and recover hydrogen: Degradation of organic compounds and characterization of microbial community. International Journal of Hydrogen Energy, 2016; 41(7): 4132-4142.

[41] Lewis A J, Ren S, Ye X, Kim P, Labbe N, Borole A P. Hydrogen production from switchgrass via an integrated pyrolysis-microbial electrolysis process. Bioresource Technology, 2015; 195: 231-241.

[42] Brooks V, Lewis A J, Dulin P, Beegle J R, Rodriguez M, Borole A P. Hydrogen production from pine-derived catalytic pyrolysis aqueous phase via microbial electrolysis. Biomass and Bioenergy, 2018; 119: 1-9.

[43] Lewis A J, Borole A P. Understanding the impact of flow rate and recycle on the conversion of a complex biorefinery stream using a flow-through microbial electrolysis cell. Biochemical Engineering Journal, 2016; 116: 95-104.

[44] Chen H, Wan J, Chen K, Luo G, Fan J, Clark J, et al. Biogas production from hydrothermal liquefaction wastewater (HTLWW): Focusing on the microbial communities as revealed by high-throughput sequencing of full-length 16S rRNA genes. Water Research, 2016; 106: 98-107.

[45] Pham M, Schideman L, Scott J, Rajagopalan N, Plewa M J. Chemical and biological characterization of wastewater generated from hydrothermal liquefaction of Spirulina. Environmental Science \& Technology, 2013; 47(4): 2131-2138.

[46] Panisko E, Wietsma T, Lemmon T, Albrecht K, Howe D Characterization of the aqueous fractions from hydrotreatment and hydrothermal liquefaction of lignocellulosic feedstocks. Biomass and Bioenergy, 2015; 74: 162-171.

[47] Yu G, Zhang Y, Schideman L, Funk T, Wang Z. Distributions of carbon and nitrogen in the products from hydrothermal liquefaction of low-lipid microalgae. Energy \& Environmental Science, 2011; 4: 4587-4595.

[48] Zheng M, Schideman L C, Tommaso G, Chen W, Zhou Y, Nair K, et al. Anaerobic digestion of wastewater generated from the hydrothermal liquefaction of Spirulina: Toxicity assessment and minimization. Energy Conversion and Management, 2017; 141: 420-428.

[49] Lu J, Li H, Zhang Y, Liu Z. Nitrogen migration and transformation during hydrothermal liquefaction of livestock manures. ACS Sustainable Chemistry \& Engineering, 2018; 6(10): 13570-13578.

[50] Lu J, Zhang J, Zhu Z, Zhang Y, Zhao Y, Li R, et al. Simultaneous production of biocrude oil and recovery of nutrients and metals from human feces via hydrothermal liquefaction. Energy Conversion and Management, 2017; 134: 340-346.

[51] Ruirui L, Xia R, Na D, Zhang Y, Zhidan L, Haifeng L. Application of zeolite adsorption and biological anaerobic digestion technology on hydrothermal liquefaction wastewater. I Int J Agric \& Biol Eng, 2017; 10(1): 163-168.

[52] Si B, Li J, Zhu Z, Shen M, Lu J, Duan N, et al. Inhibitors degradation and microbial response during continuous anaerobic conversion of hydrothermal liquefaction wastewater. Science of The Total Environment, 2018; 630: 1124-1132. 
[53] Si B, Yang L, Zhou X, Watson J, Tommaso G, Chen W, et al. Anaerobic conversion of hydrothermal liquefaction aqueous: Fate of organics and intensification with granule activated carbon/ozone pretreatment. Green Chemistry, 2018.

[54] Zeng X, Borole A P, Pavlostathis S G. Biotransformation of furanic and phenolic compounds with hydrogen gas production in a microbial electrolysis cell. Environmental Science \& Technology, 2015; 49(22): 13667-13675.

[55] Shen R, Lu J, Zhu Z, Duan N, Lu H, Zhang Y, et al. Effects of organic strength on performance of microbial electrolysis cell fed with hydrothermal liquefied wastewater. Int J Agric \& Biol Eng, 2017; 10(3): 206-217.

[56] Ahmed I N, Yang X, Dubale A A, Shao R, Guan R, Meng X, et al. Zirconium based metal-organic framework in-situ assisted hydrothermal pretreatment and enzymatic hydrolysis of Platanus X acerifolia exfoliating bark for bioethanol production. Bioresource Technology, 2019; 280: 213-221.

[57] Dimos K, Paschos T, Louloudi A, Kalogiannis K G, Lappas A A, Papayannakos N, et al. Effect of various pretreatment methods on bioethanol production from cotton stalks. Fermentation, 2019; 5(1): 5 .

[58] Thomsen M H, Thygesen A, Thomsen A B. Hydrothermal treatment of wheat straw at pilot plant scale using a three-step reactor system aiming at high hemicellulose recovery, high cellulose digestibility and low lignin hydrolysis. Bioresource Technology, 2008; 99(10): 4221-4228.

[59] Thygesen A, Marzorati M, Boon N, Thomsen A B, Verstraete W. Upgrading of straw hydrolysate for production of hydrogen and phenols in a microbial electrolysis cell (MEC). Applied Microbiology and Biotechnology, 2011; 89(3): 855-865.

[60] Zeng X, Borole A P, Pavlostathis S G. Inhibitory effect of furanic and phenolic compounds on exoelectrogenesis in a microbial electrolysis cell bioanode. Environmental Science \& Technology, 2016; 50(20): $11357-11365$

[61] Zeng X, Borole A P, Pavlostathis S G. Performance evaluation of a continuous-flow bioanode microbial electrolysis cell fed with furanic and phenolic compounds. Royal Society of Chemistry, 2016; 6: 65563-65571.

[62] Zeng X, Collins M A, Borole A P, Pavlostathis S G. The extent of fermentative transformation of phenolic compounds in the bioanode controls exoelectrogenic activity in a microbial electrolysis cell. Water Research, 2017; 109: 299-309.

[63] Iskander S M, Brazil B, Novak J T, He Z. Resource recovery from landfill leachate using bioelectrochemical systems: Opportunities, challenges, and perspectives. Bioresource Technology, 2016; 201: 347-354.

[64] Zhang G, Jiao Y, Lee D. A lab-scale anoxic/oxic-bioelectrochemical reactor for leachate treatments. Bioresource Technology, 2015; 186: 97-105.

[65] Mahmoud M, Parameswaran P, Torres C I, Rittmann B E. Fermentation pre-treatment of landfill leachate for enhanced electron recovery in a microbial electrolysis cell. Bioresource Technology, 2014; 151: 151-158.

[66] Mahmoud M, Parameswaran P, Torres C I, Rittmann B E. Fermentation pre-treatment of landfill leachate for enhanced electron recovery in a microbial electrolysis cell. Bioresource Technology, 2014; 151: 151-158.

[67] Hassan M, Fernandez A S, San Martin I, Xie B, Moran A. Hydrogen evolution in microbial electrolysis cells treating landfill leachate: Dynamics of anodic biofilm. International Journal of Hydrogen Energy, 2018; 43(29): 13051-13063.

[68] Wagner R C, Regan J M, Oh S, Zuo Y, Logan B E. Hydrogen and methane production from swine wastewater using microbial electrolysis cells. Water Research, 2009; 43(5): 1480-1488.

[69] Kiely P D, Cusick R, Call D F, Selembo P A, Regan J M, Logan B E. Anode microbial communities produced by changing from microbial fuel cell to microbial electrolysis cell operation using two different wastewaters. Bioresource Technology, 2011; 102(1): 388-394.

[70] Ibekwe A M, Murinda S E, Debroy C, Reddy G B. Potential pathogens, antimicrobial patterns and genotypic diversity of Escherichia coliisolates in constructed wetlands treating swine wastewater. FEMS Microbiology Ecology, 2016; 92(2): 1-14.

[71] Yang D, Deng L, Zheng D, Wang L, Liu Y. Separation of swine wastewater into different concentration fractions and its contribution to combined anaerobic-aerobic process. Journal of Environmental
Management, 2016; 168: 87-93.

[72] Ma D, Jiang Z, Lay C, Zhou D. Electricity generation from swine wastewater in microbial fuel cell: Hydraulic reaction time effect. International Journal of Hydrogen Energy, 2016; 41(46): 21820-21826.

[73] Zamora P, Georgieva T, Ter Heijne A, Sleutels T H J A, Jeremiasse A W, Saakes M, et al. Ammonia recovery from urine in a scaled-up Microbial Electrolysis Cell. Journal of Power Sources, 2017; 356: 491-499.

[74] Oh S, Logan B E. Hydrogen and electricity production from a food processing wastewater using fermentation and microbial fuel cell technologies. Water Research, 2005; 39(19): 4673-4682.

[75] Tenca A, Cusick R D, Schievano A, Oberti R, Logan B E. Evaluation of low cost cathode materials for treatment of industrial and food processing wastewater using microbial electrolysis cells. International Journal of Hydrogen Energy, 2013; 38(4): 1859-1865.

[76] Cusick R D, Bryan B, Parker D S, Merrill M D, Mehanna M, Kiely P D, et al. Performance of a pilot-scale continuous flow microbial electrolysis cell fed winery wastewater. Applied Microbiology and Biotechnology, 2011; 89(6): 2053-2063.

[77] Moreno R, Escapa A, Cara J, Carracedo B, Gómez X. A two-stage process for hydrogen production from cheese whey: Integration of dark fermentation and biocatalyzed electrolysis. International Journal of Hydrogen Energy, 2015; 40(1): 168-175.

[78] Wang Y, Guo W, Xing D, Chang J, Ren N. Hydrogen production using biocathode single-chamber microbial electrolysis cells fed by molasses wastewater at low temperature. International Journal of Hydrogen Energy, 2014; 39(33): 19369-19375.

[79] Sangeetha T, Guo Z, Liu W, Cui M, Yang C, Wang L, et al. Cathode material as an influencing factor on beer wastewater treatment and methane production in a novel integrated upflow microbial electrolysis cell (Upflow-MEC). International Journal of Hydrogen Energy, 2016; 41(4): 2189-2196.

[80] Cusick R D, Kiely P D, Logan B E. A monetary comparison of energy recovered from microbial fuel cells and microbial electrolysis cells fed winery or domestic wastewaters. International Journal of Hydrogen Energy, 2010; 35(17): 8855-8861.

[81] Seifert K, Waligorska M, Laniecki M. Hydrogen generation in photobiological process from dairy wastewater. International Journal of Hydrogen Energy, 2010; 35(18): 9624-9629.

[82] Montpart N, Rago L, Baeza J A, Guisasola A. Hydrogen production in single chamber microbial electrolysis cells with different complex substrates. Water Research, 2015; 68: 601-615.

[83] Wang Y, Guo W, Xing D, Chang J, Ren N. Hydrogen production using biocathode single-chamber microbial electrolysis cells fed by molasses wastewater at low temperature. International Journal of Hydrogen Energy, 2014; 39(33): 19369-19375.

[84] An Q, Wang J, Wang Y, Lin Z, Zhu M. Investigation on hydrogen production from paper sludge without inoculation and its enhancement by Clostridium thermocellum. Bioresource Technology, 2018; 263: 120-127.

[85] Lin P, Whang L, Wu Y, Ren W, Hsiao C, Li S, et al. Biological hydrogen production of the genus Clostridium: Metabolic study and mathematical model simulation. International Journal of Hydrogen Energy, 2007; 32(12): 1728-1735.

[86] Dhar B R, Elbeshbishy E, Hafez H, Lee H. Hydrogen production from sugar beet juice using an integrated biohydrogen process of dark fermentation and microbial electrolysis cell. Bioresource Technology, 2015; 198: 223-230.

[87] Li X, Liang D, Bai Y, Fan Y, Hou H. Enhanced $\mathrm{H}_{2}$ production from corn stalk by integrating dark fermentation and single chamber microbial electrolysis cells with double anode arrangement. International Journal of Hydrogen Energy, 2014; 39(17): 8977-8982.

[88] Lu L, Ren Z J. Microbial electrolysis cells for waste biorefinery: A state of the art review. Bioresource Technology, 2016; 215: 254-264.

[89] Lalaurette E, Thammannagowda S, Mohagheghi A, Maness P, Logan B E. Hydrogen production from cellulose in a two-stage process combining fermentation and electrohydrogenesis. International Journal of Hydrogen Energy, 2009; 34(15): 6201-6210.

[90] Wang A, Sun D, Cao G, Wang H, Ren N, Wu W, et al. Integrated hydrogen production process from cellulose by combining dark fermentation, microbial fuel cells, and a microbial electrolysis cell. Bioresource Technology, 2011; 102(5): 4137-4143.

[91] Lu L, Ren N, Xing D, Logan B E. Hydrogen production with effluent from an ethanol- $\mathrm{H}_{2}$-coproducing fermentation reactor using a 
single-chamber microbial electrolysis cell. Biosensors and Bioelectronics, 2009; 24(10): 3055-3060.

[92] Wu T, Zhu G, Jha A K, Zou R, Liu L, Huang X, et al. Hydrogen production with effluent from an anaerobic baffled reactor (ABR) using a single-chamber microbial electrolysis cell (MEC). International Journal of Hydrogen Energy, 2013; 38(25): 11117-11123.

[93] Liu W, Huang S, Zhou A, Zhou G, Ren N, Wang A, et al. Hydrogen generation in microbial electrolysis cell feeding with fermentation liquid of waste activated sludge. International Journal of Hydrogen Energy, 2012; 37(18): 13859-13864.

[94] Bajracharya S, Sharma M, Mohanakrishna G, Dominguez Benneton X, Strik D P B T, Sarma P M, et al. An overview on emerging bioelectrochemical systems (BESs): Technology for sustainable electricity, waste remediation, resource recovery, chemical production and beyond. Renewable Energy, 2016; 98: 153-170.

[95] Sleutels T, Molenaar S, Heijne A, Buisman C. Low substrate loading limits methanogenesis and leads to high coulombic efficiency in bioelectrochemical systems. Microorganisms, 2016; 4(1): 7.

[96] Zhang Y, Angelidaki I. Microbial electrolysis cells turning to be versatile technology: Recent advances and future challenges. Water Research, 2014; 56: 11-25.

[97] Wang H, Ren Z J. A comprehensive review of microbial electrochemical systems as a platform technology. Biotechnology
Advances, 2013; 31(8): 1796-1807.

[98] Huang L, Cheng S, Chen G. Bioelectrochemical systems for efficient recalcitrant wastes treatment. Journal of Chemical Technology \& Biotechnology, 2011; 86(4): 481-491.

[99] Badia-Fabregat M, Rago L, Baeza J A, Guisasola A. Hydrogen production from crude glycerol in an alkaline microbial electrolysis cell. International Journal of Hydrogen Energy, 2019; 44(32): 17204-17213.

[100] Lu L, Xing D, Ren N. Pyrosequencing reveals highly diverse microbial communities in microbial electrolysis cells involved in enhanced $\mathrm{H} 2$ production from waste activated sludge. Water Research, 2012; 46(7): 2425-2434.

[101] Li X, Zheng R, Zhang X, Liu Z, Zhu R, Zhang X, et al. A novel exoelectrogen from microbial fuel cell: Bioremediation of marine petroleum hydrocarbon pollutants. Journal of Environmental Management, 2019; 235: 70-76.

[102] Kadier A, Simayi Y, Abdeshahian P, Azman N F, Chandrasekhar K, Kalil M S. A comprehensive review of microbial electrolysis cells (MEC) reactor designs and configurations for sustainable hydrogen gas production. Alexandria Engineering Journal, 2016; 55(1): 427-443.

[103] Ding A, Fan Q, Cheng R, Sun G, Zhang M, Wu D. Impacts of Applied Voltage on Microbial Electrolysis Cell-Anaerobic Membrane Bioreactor (MEC-AnMBR) and its membrane fouling mitigation mechanism. Chemical Engineering Journal, 2017. 